\title{
Assessment on Practical Training in Garment Construction: The Case of Formal and Informal Institutions in the Wa Municipality of Ghana
}

\author{
Scholastica Wompakeah Azuah ${ }^{1 *} \quad$ Scholastica Wesoamo Soyeh ${ }^{2}$ \\ 1.Faculty of Applied Arts and Technology, Department of Fashion Design and Technology. Takoradi Technical \\ University. P. O. Box 256, Ghana \\ 2.School of Applied Art, Design and General Studies, Wa Technical University
}

\begin{abstract}
Most fashion design students after completing their programme in the formal sector return to the informal sector for practical training in the Wa Municipality of Ghana. It was observed that the apprentices in the informal sector were conversant with direct cutting method and seemed to be more practically inclined than students in the formal training sector of the Municipality. The study therefore assessed the methods of cutting-out in garment construction course by trainees in the formal and informal sectors. Data collected from the trainees and trainers in the formal and informal institutions of the Wa Municipality. Two hundred and forty (240) students from the formal institutions, 120 trainees from the informal institutions, 18 formal trainers (teachers) and 60 informal trainers were sampled for the study. Results of the study revealed that teachers and students in the formal institutions were not conversant with the direct cutting method due to lack of standard books and were not keen at teaching direct cutting. Trainers and trainees in the informal institutions were conversant with both direct cutting and pattern drafting methods but also complained on the non-availability of documented instructions on direct cutting method. Student trainees in the formal institutions did not also have adequate practical periods making them inadequately fit to join the fashion industry. The trainees in the informal institutions though regarded as 'roadside' products, acquired skills in direct cutting method and could establish businesses though their cutting method wastes fabric and time. The direct cutting has also becomes the most common method engaged by many dressmakers in Ghana. The study recommends fashion scholars publish books on the right drafting method for direct cutting and the Ministry of Education to review the TVET curriculum, allocating more time for practical training and acquisition of skills.

Keywords: Cutting-out methods, Trainees, Formal sector, Informal sector, Wa Municipality, Skills
\end{abstract}

DOI: $10.7176 / \mathrm{JEP} / 13-1-03$

Publication date: January $31^{\text {st }} 2022$

\section{Introduction}

Technical and vocational education affords an individual the chance to acquire practical knowledge and requisite skills training needed in the job market or for immediate self-employment (Amubode \& Folade, 2012). According to Charway (2002) the major objective of the formal system is to equip individuals with employable skills to enable them contribute meaningfully towards the development of the nation. In the study of Amedoeme \& Fiagbe (2013), no country can develop without quality Technical and Vocational Education and Training (TVET).

Three different forms of TVET have evolved in Ghana over the years. These comprise the formal system, the non-formal system and the informal system. Individuals who opt to pursue this form of training selects from these systems depending on their goals and aspirations, expenses involved among many other factors (Bortei-Doku, Doh \& Andoh, 2011).

The formal system of vocational and technical training includes primarily time-bound, institution based, graded, and certified training. It is offered by institutions such as the National Vocational Training Institutes (NVTI), Ghana Education Service (GES) Technical Institutes, Youth Training Institutions and a variety of private Vocational Training Schools (Bortei-Doku et al, 2011). Courses such as motor vehicle mechanics, Electrical works, Welding and fabrication, Carpentry and Joinery, Block laying and Concreting or Masonry, Plumbing, Tailoring and Dressmaking or Fashion design are mounted to give practical training to students.

In achieving maximum results of this practical training, Bortei-Doku et al (2011) indicate that certain factors should come into play. These include the availability of qualified and competent teachers to teach, availability and adequacy of learning facilities and materials for training students, conducive training environment and students' discipline. Acheampong (2002) also added that the supply of vocational workshops and laboratories in all schools with adequate modern equipment for practical lessons are also factors that can bring on board the success of vocational training.

The non-formal system of training typically has structured learning objectives, learning times and learning support but will normally not lead to certification. Workshops, short courses and seminars are all forms of nonformal learning. Under this system, both non-governmental agencies and the government of Ghana have developed a number of programmes to help train, improve, and support individuals and associations in the technical and 
vocational sectors. In the study of Asare (2015), some of these programmes include:

1. The Local Enterprises and Skills Development Programme (LESDEP), a private-public initiative by the Ministry of Local Government and Rural Development in collaboration with the Ministry of Employment and Social Welfare. This programme aims at alleviating poverty, especially among the youth, through training and equipping them to set up their own businesses.

2. The Skills Training and Entrepreneurship Programme (STEP) which is intended to reduce poverty by providing employable skills and other assistance including micro-finance to the unemployed.

3. The Development of Skills for Industry Project (DSIP), an African Development Bank (AfDB) sponsored project, aimed at providing harmonized standards of training for apprentices and to improve their knowledge and skills in the Competency Based Training (CBT) method. This project is implemented by the Project Support Unit of the Council for Technical and Vocational Education and Training (COTVET).

The informal system includes a wide range of flexible programme and processes by which individuals acquire skills and knowledge from designated training venues within and outside of the home (Asare, 2015). According to Uwameiye \& Iyamu (2010), traditional apprenticeships make up the majority of the informal sector in Ghana. Apprenticeship programme provides an opportunity for individuals who cannot afford to further their formal education gain employable skills. There is the therefore the need to strengthen the training methods to avoid disparities in services render by both informal and formal fashion designers.

In most cases, apprenticeship training progresses in phases with most beginning with an introductory phase during which the beginner is taught and made to do menial jobs such as cleaning the workshop or running errands and also observing the work. The next phase consists of getting to know all tools and materials. Gradually the apprentice is then introduced to more complex tasks and given increased responsibility such as supervising other apprentices, dealing directly with customers, and from time to time, looking after the shop in the absence of the established dressmaker (Abban \& Quarshie, 1993).

Asare (2015) indicates that the skills, knowledge, and attitudes are normally transmitted through observation, imitation and on-the-job experience. With the present system of apprenticeship, established dressmakers teach their apprentices what they were taught and usually, there is little infusion of new technology and new designs. The masters mostly pass on trained skills and knowledge acquired to their apprentices, but rarely create new knowledge. There are no formal instructions with this system. This normally limits the theoretical base of apprentices leaving then without the ability to explore and learn new skills and technology. The absence of programmes on skills upgrade for the informal sector creates a gap in services rendered to the general public.

Patience (1997) observed that there are two main informal training modes, each having its own characteristics and outcome. The two modes were fostering and vocational apprenticeships.

Fostering apprenticeship according to Patience (1997) occurred between kin relatives, that is, the master (trainer) is related to the family of the apprentice. This type of apprenticeship is typified by very little, or no cash payment being required for the training, but rather a relatively long apprenticeship period of five to seven years.

The vocational apprenticeship required a shorter apprenticeship period which usually began from late adolescence (17-19 years old). The trainer often called Master / Madam is responsible for the training. The apprentices do not live with them and mostly are not related to them also. The apprentices pay training fees and provide their own sewing machines, and other basic tools for the training. It was further revealed that the fees for apprenticeship training is generally lower than the cost of training in the formal school system. As such parents of low-income occupations who are unable to pay the high cost of formal training for their children, normally send them into apprenticeship.

In the informal sector, the competency of a trainee is ascertained by the trainer by regularly assessing the trainee's level of progress in skill performance. Martha (2014) stated that "Masters" test the proficiency of their apprentices by assigning them specific jobs related to their training needs. When the master or trainer is satisfied with the apprentice's performance at the end of the training period, the trainee is allowed to leave finally. Graduation ceremony which is often referred to as "freeing" is organized for the trainees in recent times where certificate of completion of apprenticeship is presented to them.

Construction of clothing in Ghana is mostly done by seamstresses who cut to fit the customer. Cutting of fabrics cannot be achieved without drafting a pattern according to specific measurements. There are two ways of drafting patterns manually; drafting on a brown paper or directing drafting on the fabric. Directing drafting on the fabrics in Ghana is generally termed "free hand cutting". Fianu \& Zentey (2000) indicate that direct cutting is the most common, simplest, fastest and easy to learn method of cutting fabric for garment construction. A technique which every person can learn easily without passing through formal education. Research has shown that direct cutting is the most common method of cutting fabric for garment construction by the dressmakers in Ghana and other African countries. However, the difference in quality regarding fitting as compared to cutting with the pattern is wide though direct cutting is widely spread.

The TVET syllabus for Technical and Vocational Institutes produced by the Ministry of Education (2010), required teachers to demonstrate how to cut a garment before proceeding to supervise students do same first on 
paper before using fabric. To make sure students practice direct cutting, the syllabus suggests that each student should complete the garment he/she cuts for evaluation. However, there is lack of documented information on direct cutting method making teaching of the concept difficult in the formal training sector as indicated by Forster (2009).

Many teachers concentrate on teaching students pattern drafting on paper to the neglect of the direct cutting which is a normal practice in the informal sector. Foster (2009) noted that the skill of direct cutting is acquired through constant or continuous practice but time allocated for this sector is inadequate as compared to the other sector.

In Ghana it is observed that, students after completing their course of study in the school system found themselves in the informal sector for more practical orientation. Reason being that most trainees in the informal sector are conversant with direct cutting method and seem to be more practically inclined than those from the formal training sectors. It is on this backdrop that this research seeks to specifically examine cutting-out methods for garment construction and to make a comparative assessment of methods used for training in the formal and informal institutions at the Wa Municipality.

\subsection{Methodology}

The study employed the descriptive survey approach to assess the usage of direct cutting method for garment construction by trainees in the formal and informal institutions in the Wa Municipality.

The study focused on the formal and informal institutions with emphasis on TVET institutions, and fashion design enterprises that give training to apprentices in the municipality. The municipality has only two (2) Technical and Vocational Institutes and one (1) Technical University as TVET institutions which formed part of the study. The population comprised students, apprentices, teachers, and trainers in both formal and informal institutions. A target population of four hundred (400), one hundred and fifty (150) and one hundred (100) for fashion design students, apprentices and teachers/trainers respectively formed the study.

The stratified sampling technique was used because of the heterogeneous nature of the study population, made up of teachers and trainees from formal institutions, trainers, and trainees (apprentices) from the informal setting. The population was stratified into four; teachers and students (formal) and trainers and apprentices (informal).

For the formal sector, a simple random sampling technique was used to select sixty percent $(60 \%)$ of the students from each institute of the study using a randomizer software.

For Wa Technical Institute, a list of the fashion design students was obtained, and a number assigned to each student name, from 1-250. A randomizer software was set to randomly generate 150 numbers from the 250 numbers which constituted $60 \%$ of the students in the institute. This means that 150 students were sampled from Wa Technical Institute for the study. For Community Development Institute and Wa Technical University, the same procedure was followed to sample 72 and 18 students respectively. A sample size of 240 students was obtained from all the formal institutions. In all 18 teachers were used for the study with a total sample size of 258 students and teachers obtained.

For the informal sector, all the registered fashion design enterprises were numbered from 1-150. A randomizer was set to randomly generate sixty (60) of the enterprises for the study. From each of the enterprises, two (2) apprentices and one (1) trainer were randomly selected for the study. This gave a sample size of one hundred and eighty (180). A total sample size of 438 from both the formal and the informal institutions was obtained for the study as determined by Fisher (2007. Observations, questionnaires, and structured interview were employed to collect the necessary data.

The trainee sample used was 360, consisting of 240 from the formal institutions and 120 from the informal sector. Seventy-eight (78) trainers were also administered questionnaire to confirm on certain issues regarding the responses from the trainees. This comprised of 18 trainers/teachers in the formal institutions and 60 trainers from the informal institutions.

\subsection{Results and Discussion}

\subsection{Teacher/Trainer Practical Training Methods}

The objective of this item was to find out practical training methods engaged by the teachers and trainers in the formal and informal sectors in the WA Municipality. Respondents were asked to state methods used in training of students/apprentices. 
Figure 1. Method of Training Employed by Teachers/Trainers during Practical Lessons

\begin{tabular}{llll}
\hline Response & Status & Frequency & Percent \\
\hline Direct Cutting & Student & 25 & 6.9 \\
Pattern drafting & Student & 211 & 58.6 \\
Both Direct and Pattern & Apprentice & 120 & 33.3 \\
Others & Student/App & 4 & 1.1 \\
\hline Total & & 360 & 100.0
\end{tabular}

Source: Field data, 2021

In asking respondents the type of methods trainers normally used in teaching them, $58.6 \%$ trainees in the formal institutions said their teachers normally use pattern drafting to teach them, and $6.9 \%$ trainees in the formal institution indicated that their teachers use direct cutting method.

For the informal sector, all the trainees indicated that their trainers normally use both direct and pattern drafting methods in teaching them. A little above $1 \%$ of the trainees in both the formal and informal institutions indicated that their trainers use other method in teaching them (Figure 1). Even though the results revealed that both informal and formal trainers used the two methods of achieving patterns or cutting-out our observation also have it that the extent to which the informal sector used pattern drafting in cutting-out is low. This findings explain Fianu \& Zentey (2000) assertion that direct cutting is the most common, simplest, fastest and easy to learn method of cutting fabric for garment construction. A technique which every person can learn easily without passing through formal education. But confirmed the statement which indicate many teachers concentrate on teaching students pattern drafting on paper to the neglect of the direct cutting which is a normal practice in the informal sector. Foster (2009) on the other hand noted that the skill of direct cutting is acquired through constant or continuous practice but time allocated for this sector is inadequate as compared to the other sector.

\subsection{Usage rate of Cutting/drafting Training Methods in Formal Institutions}

The table below presents the rate of training methods usage in the formal institutions of the municipality. It also tried to reveal the frequency rate of these methods.

Figure 2. Direct Cutting / Pattern Drafting Training in Formal Institutions

\begin{tabular}{llrr}
\hline Response & Status & Frequency & Percent \\
\hline Direct Cutting & Teacher & 5 & 6.4 \\
Pattern drafting & Teacher & 10 & 12.8 \\
Both Direct and Pattern & Trainer & 57 & 73.1 \\
Others & Teacher/Trainer & 4 & 5.1 \\
Missing & Teacher/Trainer & 2 & 2.6 \\
\hline Total & & $\mathbf{7 8}$ & $\mathbf{1 0 0 . 0}$ \\
\hline
\end{tabular}

Source: Field data, 2021

In Figure 2, trainers/teachers in the formal institutions were asked to state the type of cutting-out methods used during practical lessons. Out of the 78 teachers/trainers, $6.4 \%$ indicated they use direct cutting while $12.8 \%$ stated pattern drafting, $73.1 \%$ claimed using both direct and pattern drafting in their garment construction, $5.1 \%$ indicated other methods, whilst $2.6 \%$ did not indicate anything. From figure 5 , those who indicated the engagement of both direct and pattern drafting were from the informal institutions. Direct cutting is a practical form of cuttingout directly on the fabrics using an individual body measurement (Forster (2009) while pattern drafting in clothing construction is a process of attaining patterns on paper (Gavor, 2011). The formal sectors agreed using both methods for cutting-out, but the frequency of direct cutting usage was low as compared to pattern drafting. Forster 2009 explained this by stating, there was lack of documented information on direct cutting method making teaching of the concept difficult in the formal training sector.

These statistics confirmed the position of Martha (2014) that direct cutting is mostly practiced by the informal sector while the formal more often uses pattern drafting method. This goes to confirm our observations that apprentices in the informal sector are more practically oriented than those in the formal setting because of the constant exposure to various methods of cutting each day. The continual engagement of wider range of methods in garment construction facilitates rapid skills improvement in the field.

All methods or skills are supposed to be learned by all fashion design and textile trainees either in the formal or informal sector to make them competent and constructive. However, direct cutting training seems to be limited in the formal setting while pattern drafting is higher. 


\subsection{Period Spend on Practical Lessons in formal institutions}

\section{Figure 3: Period Spent on Practical Lessons}

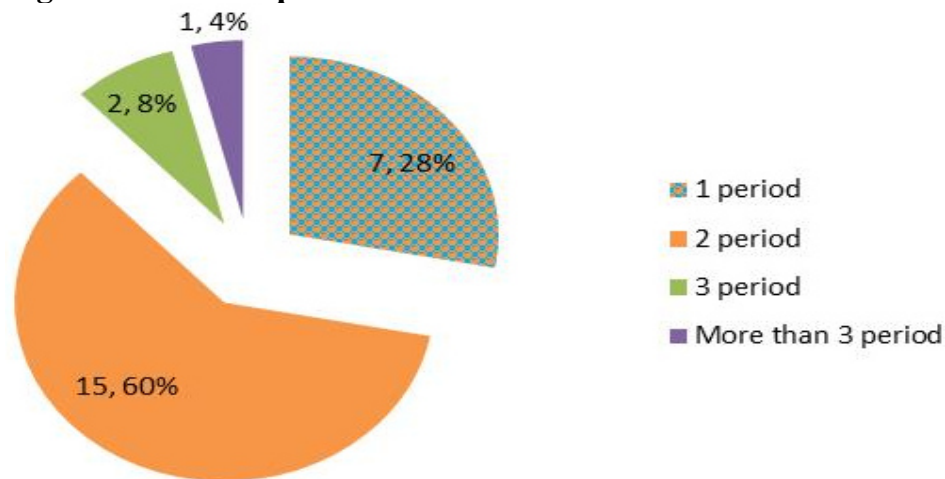

Source: Field data, 2021

In Figure 3, sixty percent of trainees indicated that, they normally use 2 periods for practical lesson, 28\% use 1 period for practice, $8 \%$ use 3 periods whilst $4 \%$ use more than 3 periods for practice training as shown in figure 2. The result affirmed that practical training period is woefully inadequate for skills acquisition in the formal sector as against time dedicated to practical training in the informal sector instead. $1.4 \%$ indicated they used more than 3 periods in their practical lesson. The finding suggested majority of training institutions used lesser periods in doing practicals which is inadequate for direct cutting. According to Foster (2009), the skill of direct cutting is acquired through constant or continuous practices.

In the informal institutions, all 120 apprentices revealed that they have no time limit for doing practicals. Sometimes they could sew into the night or throughout when it is an occasion period. The duration of training in this method might be reason for the fast acquisition of skills as indicated by Fianu \& Zentey (2000) that direct cutting is the most common, simplest, fastest and easy to learn method of cutting fabric for garment construction.

3.4 Level of Satisfaction in Direct Cutting-Out Training Figure 4: Level of Satisfaction in Direct Cutting-out Training

\begin{tabular}{llrr}
\hline Response & Status & Frequency & Percent \\
\hline Satisfied & Apprentice & 40 & 11.1 \\
Very satisfied & Apprentice & 80 & 22.2 \\
Not satisfied & Student & 210 & 58.3 \\
Missing value & Student & 30 & 8.3 \\
\hline Total & & 360 & 100.0 \\
\hline
\end{tabular}

Source: Field data, 2021

On the level of satisfaction in direct cutting-out training method presented in Figure 4 below, 58.3\% made up of 210 students were not satisfied while $33.3 \%$ were satisfied. The TVET syllabus for Technical and Vocational Institutes produced by the Ministry of Education (2010), required teachers to demonstrate direct cutting on fabrics before proceeding to supervise students do same first on paper before using fabric. However, as stated by Forster (2009), lack of documented information on direct cutting method makes teaching of the concept difficult. If students were not satisfied with the nature of training in direct cutting, it was also attributed to the fact that students in the formal sector believe direct cutting is for the way-side seamstresses.

3.5 Difficulty in Practicing Direct Cutting-out Figure 4: Difficulty in Practicing Direct Cutting-out

\begin{tabular}{llrr}
\hline Response & Status & Frequency & Percent \\
\hline Yes & Students/Apprentice & 360 & 100.0 \\
No & Students/Apprentice & 0 & 0.0 \\
\hline Total & & $\mathbf{3 6 0}$ & $\mathbf{1 0 0 . 0}$ \\
\hline
\end{tabular}

Source: Field data, 2021

An observation of the data on Figure 4 revealed that all trainees in both formal and informal sector asserted that they have difficulty in practicing direct cutting due to the numerous ways of cutting-out without standardized instructions. However, Fianu \& Zentey (2000) was of the view that direct cutting is the most fastest and easy to learn method of cutting fabric for garment construction. Their statement was disputed by Forster (2009) where she revealed that there is lack of documented information on direct cutting method making teaching of the concept difficult in the formal training sector. 


\section{Conclusion}

Vocational technical training in Ghana comprises two main sectors; the formal and informal within which fashion design training is the most practiced field that has students and apprenticeship training. There are two methods of cutting-out in garment construction; direct cutting on fabric or pattern drafting on paper. While all sectors employ both in their training, the formal sector engages pattern drafting most with the informal trainees practicing direct cutting method in their day-to-day acquisition of sewing skills. The ability of students completing formal education to gain self-employment has become a challenge due to their inability to fully practice the trade because of inadequate training. It is recommended that TVET should institute programmes for fashion designers to get abreast with pattern drafting skills for easier transfer of learning in direct cutting method training. Trainers/teachers should employ adequate methods during practical lessons for students to become more conversant with practicals and improve on their creativity and skills. Curriculum developers in the Ghana Education Service and the Ministry of Education should review the TVET curriculum ensuring more periods allocated for practical subjects to enable trainees improve and expand their practical knowledge and skills. Finally, the trainees in the TVET schools should be allowed to undertake industrial attachment for at least two months during holidays to enable them acquire industrial skills which would improve on their drafting skills.

\section{References}

Abban, C. K. \& Quarshie, S. O. (1993), Report on upgrading the Technical and Managerial skills of master mechanics and apprentices. Journal of Education and Practice.

Amedorme,S.K., \& Fiagbe, Y.A.K. (2013), Challenges Facing Technical and Vocational Education in Ghana. International journal of scientific \& technology research, 2, 253-254.

Ameleke, G. (2015), Teachers' views about the teaching of Clothing and Textiles in Senior High Schools in the southern Volta Region, Ghana. Unpublished dissertation, University of Education, Winneba.

Amubode, A. A., \& Folade, B. O. (2012). Female consumers' expectations and post patronage satisfaction of tailoring services in Ibadan metropolis. Journal of Home Economic Research.

Asare, D. A (2015). Assessment of Dressmakers knowledge base on darts and their application in Garment Designing in the Central Region. University of Cape Coast. Ghana.

Arubayi, D. (2006). Student Enrolment, Academic Staff Quantity and Teachers Students Ratio in Home Economics in Colleges of Education in Nigeria. Journal of Educational Research and Development, 5(1), 118-204.

Bortei-Doku, A. E., Doh, D. \& Andoh, P. (2011). Study of attitudes towards Technical and Vocational Education and Training in Ghana. Centre for Social Policy Studies, University of Ghana.

Charway A. S (2002). Encouraging vocational education in Ghana (III). Yetoda, Accra.

Fianu D. G, Zentey EA (2000). Problems of large-scale fashion designers in Accra, Ghana. J. Consumer Stud. Home Economics, 24 (2), 128-136.

Forster, P. (2009). Free-hand cutting made easy. Winneba: Department of Home Economics Education, University of Education. Ghana.

Gavor, M. E., \& Danquah, P. A. (2018). Assessment of the Teaching of Pattern Making and Freehand Cutting Skills in Ghanaian Senior Secondary Schools. Cape Coast, Ghana. International Journal of Vocational Education and Training Research.

Ghana Education Service (2010). Teaching syllabus for Clothing and Textiles (Senior High School 1-3). Accra: Ministry of Education publication.

Martha, K. (2014). Prospects of 'sideway' garment construction. Nigeria, Isenberg Ltd.

Patience, A. (1997). Apprenticeship system of 'Wayside' seamstresses from selected neighborhoods in Accra. A thesis presented to the Department of Home Science for the Award of Master of Philosophy degree, University of Ghana.

Uwameiye, R. \& Iyamu, O. S. (2010). Training Methodology used by Nigerian Indigenous apprenticeship system (online) Retrieved on September, 13, 2018 from http://www.iizdvv.de/index.php 